\title{
Nitrous oxide emission from conservation forest of Kampar Peninsula peatland ecosystem
}

Nardi ${ }^{\mathrm{a}}$, Syaiful Anwar ${ }^{\mathrm{b}}$, Mohamad Yanic, Nurholis ${ }^{\mathrm{d}}$, Muhammad Hendrizal ${ }^{\mathrm{d}}$

${ }^{a}$ Natural Resources and Environmental Management Study Program, Graduate School, IPB University, Bogor 16680, Indonesia

${ }^{\mathrm{b}}$ Department of Soil Science and Land Resources, Faculty of Agriculture, IPB University, Bogor 16680, Indonesia

${ }^{c}$ Department of Agricultural Industrial Engineering, Faculty of Agricultural Technology, IPB University, Bogor 16680, Indonesia

d Asia Pacific Resources International Limited, Riau, Indonesia

\section{Article Info:}

Received: 28 - 08 - 2021

Accepted: $19-10-2021$

Keywords:

Environmental factors, global warming, greenhouse gas, inorganic $\mathrm{N}$, soil moisture

Corresponding Author: Syaiful Anwar

Department of Soil Science and

Land Resources, Faculty of

Agriculture, IPB University;

Phone. +6281316048986

Email:

phuy@apps.ipb.ac.id

\begin{abstract}
Nitrous oxide (N2O) is a long-lived greenhouse gas with a warming potential of 300 times higher than $\mathrm{CO}_{2}$. Conserving of intact peat swamp forest can hold the natural physical and chemical properties of the soil, such that the $\mathrm{N}_{2} \mathrm{O}$ emission occurs naturally. To quantify $\mathrm{N}_{2} \mathrm{O}$ emission from peatland ecosystems, data availability is highly needed. The objectives of this study were to quantify the emission of $\mathrm{N}_{2} \mathrm{O}$ and determine the main factors controlling $\mathrm{N}_{2} \mathrm{O}$ emission from peatland conservation forests. This research was conducted from January to December 2020 in the Kampar Peninsula, Pelalawan Regency, Riau Province. We employed the static metallic manual ground chamber to collect gas samples and analyzed them using gas chromatograph equipped with electron capture detector. This study found that $\mathrm{N}_{2} \mathrm{O}$ emission at peatland conservation forest was $0.23 \pm 0.19 \mathrm{~kg}-\mathrm{N} / \mathrm{ha} /$ year. Substantial changes in soil and environmental factors such as water table, soil temperature, soil moisture, water-filled pore space, $\mathrm{NH}_{4}-\mathrm{N}$, and $\mathrm{NO}_{3}-\mathrm{N}$ significantly affect the exchange and magnitude of $\mathrm{N}_{2} \mathrm{O}$ between peatlands and the atmosphere.
\end{abstract}

How to cite (CSE Style $8^{\text {th }}$ Edition):

Nardi, Anwar S, Yani M, Nurholis, Hendrizal M. 2021. Nitrous oxide emission from conservation forest of Kampar Peninsula peatland ecosystem. JPSL 11(3): 442-452. http://dx.doi.org/10.29244/jpsl.11.3. 442-452.

\section{INTRODUCTION}

In terms of climate change study, the peat ecosystem has a significant role in various biogeochemical cycles of greenhouse gases. Both temperate and tropical peatlands play a major role in gas exchange with the atmosphere, as they are the mainstream greenhouse gases (Nunes et al., 2020). The most dominant greenhouse gas emissions in peatlands are carbon dioxide $\left(\mathrm{CO}_{2}\right)$, followed by methane $\left(\mathrm{CH}_{4}\right)$ and nitrous oxides $\left(\mathrm{N}_{2} \mathrm{O}\right)$ emissions. $\mathrm{N}_{2} \mathrm{O}$ is a long-lived greenhouse gas with a greenhouse gas potential of 300 times higher than $\mathrm{CO}_{2}$ (IPCC, 2014; Sakabe et al., 2018). Tropical forests are still considered a major source of $\mathrm{N}_{2} \mathrm{O}$ emissions to the atmosphere (Werner et al., 2007). The increase in $\mathrm{N}_{2} \mathrm{O}$ in the atmosphere due to human activities affects the global climate, human health, and the function of ecosystems that are very sensitive to climate change (Fowler et al., 2013).

Many researchers consider that climate change has become the greatest challenge for humanity. Several natural and artificial activities are responsible for global warming, affecting the environment and humans. The current climate change has become a worldwide concern because it does have not only an impact on the environment but also human life (Fowler et al., 2013). Therefore, it is very important to find solutions to reduce 
climate change (Nunes et al., 2020). Increased $\mathrm{CO}_{2}, \mathrm{CH}_{4}, \mathrm{~N}_{2} \mathrm{O}$, and water vapor $\left(\mathrm{H}_{2} \mathrm{O}\right)$ in the air contribute to global warming (Khare et al., 2020). The accumulation of greenhouse gases that form a thin layer in the atmosphere makes the air temperature hotter on the earth's surface. The Kampar Peninsula peat ecosystem covers about 722.929 ha and peat thickness ranging between 5 to $10 \mathrm{~m}$ (Arvelyna et al., 2019), making it one of the largest peat carbon reservoirs in Southeast Asia (Karyanto et al., 2015). Tropical peatlands store large amounts of carbon formed over a long time under water-saturated conditions. The nature of Indonesian peatlands varies significantly in terms of physical, chemical, and biological properties and environmental conditions. These varying conditions of peat properties indicate that peatlands can be used for agricultural development and some that need to be maintained to preserve the environment (Masganti, 2013).

The study on $\mathrm{N}_{2} \mathrm{O}$ gas emissions in various ecosystems has not been done much compared to $\mathrm{CO}_{2}$ and $\mathrm{CH}_{4}$ gas emissions. Melling et al. (2007) explained that the highest $\mathrm{N}_{2} \mathrm{O}$ emissions occurred in sago plantations with a production rate of $3.3 \mathrm{~kg}-\mathrm{N} / \mathrm{ha} /$ year, followed by oil palm plantations at $1.2 \mathrm{~kg}-\mathrm{N} / \mathrm{ha} / \mathrm{year}$ and mixed peat swamp forest at $0.7 \mathrm{~kg}-\mathrm{N} / \mathrm{ha} /$ year. Conversion of peat swamp forest can cause major changes in the environment and the physical and chemical properties of the soil that will affect the $\mathrm{N}_{2} \mathrm{O}$ cycle (Melling et al., 2007). Peatland management into agricultural land can cause high $\mathrm{N}_{2} \mathrm{O}$ gas emissions, while forest areas still maintained have lower emissions (Takakai et al., 2006). Melling et al. (2007) stated that $\mathrm{N}_{2} \mathrm{O}$ emissions from peatlands are strongly influenced by environmental factors: groundwater level.

Studies of $\mathrm{N}_{2} \mathrm{O}$ emissions in tropical peatlands especially in Kampar Peninsula is remain overlooked despite of the lowest contribution to the GHG balance. Therefore, it is important to quantify the contribution of $\mathrm{N}_{2} \mathrm{O}$ emissions from conservation forests. This research is part of a large study conducted in Kampar Peninsula related to greenhouse gas emissions $\left(\mathrm{CO}_{2}, \mathrm{CH}_{4}\right.$ and $\left.\mathrm{N}_{2} \mathrm{O}\right)$ from different land-use types: conservation forest, acacia plantations, shrubs, and burnt land with measurements from the ground and above canopy. The measurement of greenhouse gas emissions from the ground is carried out using automatic and conventional chamber, while the measurement of emissions above the canopy uses a tower (Eddy covariance tower). We expect that $\mathrm{N}_{2} \mathrm{O}$ emission at the natural condition will be insignificant due to less of nitrogen input as the main raw material to break down the chemical cycle into the nitrous oxide. This study aims to determine the $\mathrm{N}_{2} \mathrm{O}$ gas emission factor from peatland conservation forests and determine the main drivers that influence the $\mathrm{N}_{2} \mathrm{O}$ gas emissions.

\section{METHOD}

\section{Study Area and Period}

This research was conducted from January to December 2020 on the peatlands of the Kampar Peninsula, Pelalawan Regency, Riau Province. The Kampar Peninsula is one of the peat hydrological units (i.e. KHG) with the code KHG.14.05-08.01. The sampling location has been done atthe Riau Ecosystem Restoration (RER) with the area more than 100.000 hectares (Figure 1a) which is managed to protect biodiversity. Determination of sampling location was using purposive sampling method and the sampling locations were divided into three, namely conservation forest 1 (CF1), conservation forest 2 (CF2) (Figure 1b), and conservation forest 3 (CF3) with a distance between observation locations of 700 to 1000 meters. The observation site is set within a $2 \mathrm{~km}$ radius of the greenhouse gas (GHG) emission measurement tower above the canopy, the framework for a larger GHG emission research project covering $\mathrm{CO}_{2}, \mathrm{CH}_{4}$ and $\mathrm{N}_{2} \mathrm{O}$ gases. At each location, six hoods are installed with a distance between them of about 10 to $30 \mathrm{~m}$. The hoods are installed in high and low areas to represent the peat surface's micro-topographic conditions in conservation forests. At each conservation forest observation location, a piezometer was installed to manually measure the ground water level at the time of gas sampling. 

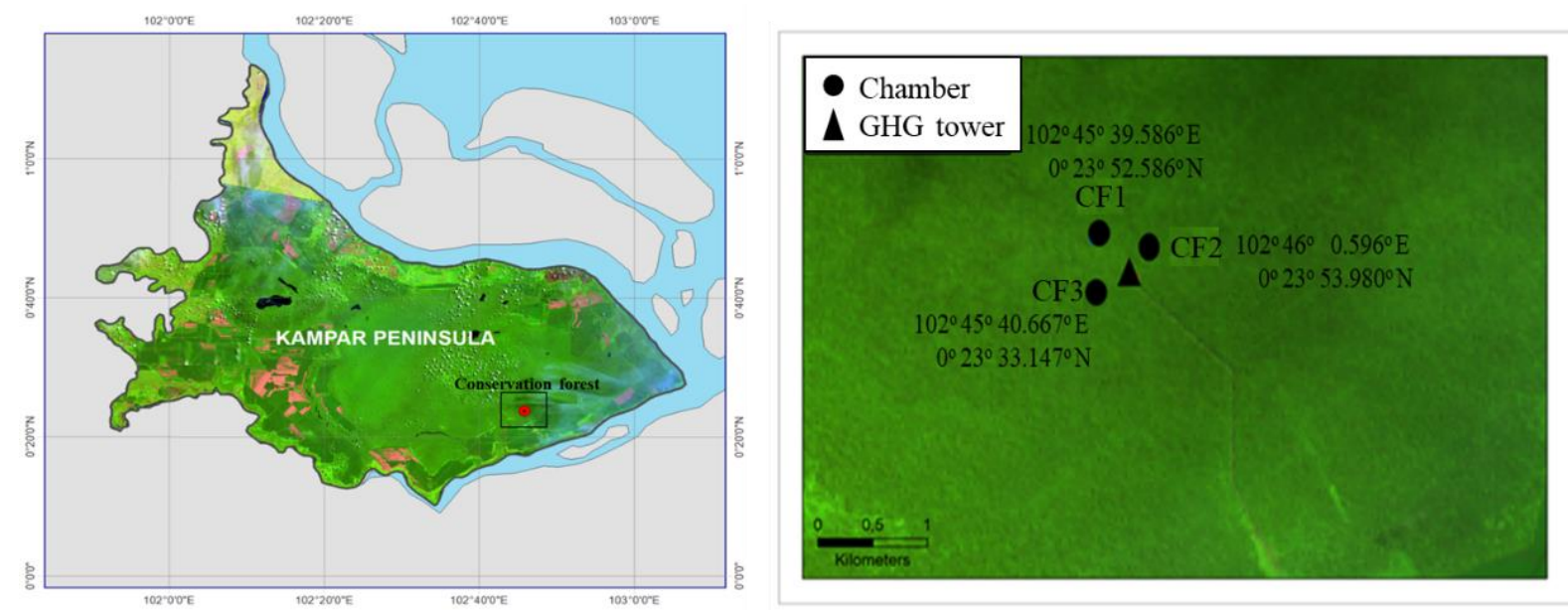

Figure 1 Study area: (a) Kampar Peninsula, Pelalawan Regency, Riau Province,

KHG.14.05-08.01; and (b) three observation points in conservation forests (CF1, CF2, and CF3) and GHG tower

\section{$\mathrm{N}_{2} \mathrm{O}$ Gas Sampling and Analysis}

Samples of $\mathrm{N}_{2} \mathrm{O}$ gas emissions were collected using a conventional closed hood technique with a base dimension of $30 \mathrm{~cm} \times 15 \mathrm{~cm}$ and a height of $15 \mathrm{~cm}$ made of stainless steel with a thickness of $2 \mathrm{~mm}$. Technically, the hood is equipped with a hole covered with a rubber stopper as a place for gas sampling (Figure 2). At each containment point, a collar (frame) was first placed, which was immersed in the ground about one month before the first gas extraction (until the physical disturbance to the soil due to the immersion of the collar was removed) and left and protected from disturbance (physical) during the study. The collar is made of the same material and has the exact dimensions as the lid but is equipped with a canal/trench at the top with 2 $\mathrm{cm} \times 1.5 \mathrm{~cm}$ (Figure 2). The canal/trench in this collar serves to accommodate the water given just before the hood is placed so that there is no gas leak during sampling. Gas sampling was carried out in January, April, and from June to December carried out monthly, in this case ignoring daily variations. Gas samples were taken in the time range from 10.00 to $15.00 \mathrm{PM}$.

Gas sampling was carried out using a $50 \mathrm{ml}$ syringe, then put into a $20 \mathrm{ml}$ sample bottle that had been vacuumed using a $\mathrm{NaCl}$ solution with a concentration of $80 \%$, aiming to avoid air contamination in the sample bottle. The time interval for gas sampling is every 15 minutes after the hood is installed, namely at $0,15,30$, and 45 minutes. All samples that have been taken are put into a cooler box to avoid direct sunlight contact, then analyzed in the laboratory in no more than 24 hours.

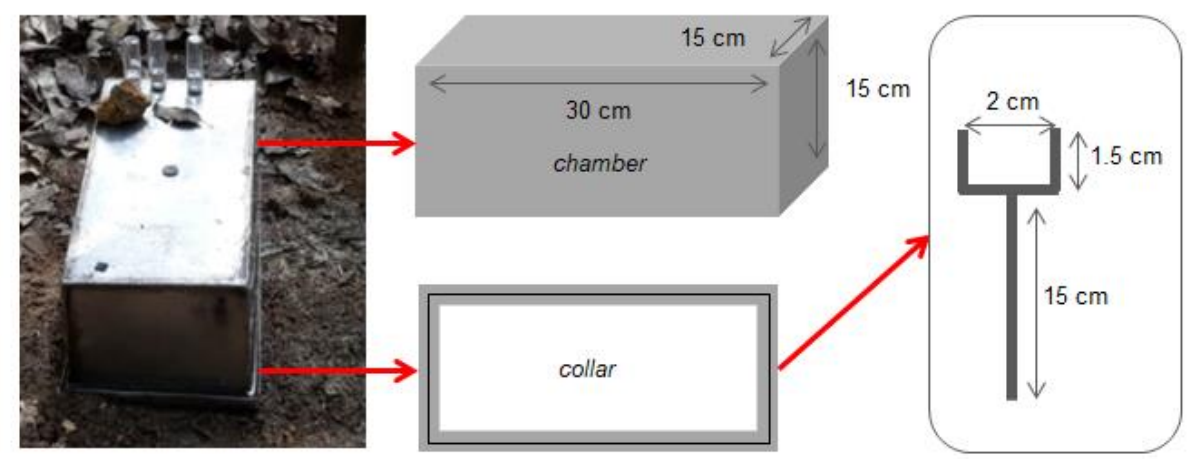

Figure $2 \mathrm{~N}_{2} \mathrm{O}$ gas extraction equipment using a hood and collar design (frame) 


\section{Supporting Parameter Measurement}

Supporting parameters measured in this study are environmental parameters and parameters of soil physical and chemical properties. Environmental parameters include groundwater level, rainfall, soil moisture, and soil temperature. Measurement of groundwater level is carried out in two ways, namely automatic and manual. The daily ground water level is automatically measured using a solinst levelogger (model 3001 ) with a recording frequency of every 30 minutes to represent the entire location of conservation forests. Measurement of water level manually was carried out on piezometers at each conservation forest at the time of sampling $\mathrm{N}_{2} \mathrm{O}$ gas. Daily rainfall is measured automatically with a rain gauge bucket (part of the equipment of the GHG tower) with a recording frequency of every 30 minutes. Soil moisture and soil temperature were measured at a depth of $15 \mathrm{~cm}$ using a steven hydra probe when returning the $\mathrm{N}_{2} \mathrm{O}$ gas sample.

The measured soil chemical parameters included $\mathrm{pH}, \mathrm{C}$-organic, $\mathrm{N}$-total, $\mathrm{NH}_{4}{ }^{-} \mathrm{N}, \mathrm{NO}_{3}-\mathrm{N}, \mathrm{P}$-available, and $\mathrm{K}$-available. The physical parameters measured were fiber volume, bulk density, porosity, and water-filled pore space (WFPS). Soil samples were taken using a peat sampler with a volume of $0.5 \mathrm{~L}$, for the physical parameters of the soil samples were taken at a depth of $0-50 \mathrm{~cm}$ and $50-100 \mathrm{~cm}$, while the chemical parameters of the soil samples were taken at a depth of $0-15 \mathrm{~cm}, 15-30 \mathrm{~cm}$, and $30-50 \mathrm{~cm}$. Soil samples for physical and chemical parameters were taken at four points in each $\mathrm{N} 2 \mathrm{O}$ gas extraction hood; then soil samples were composited per depth to represent the gas sampling point. Wet peat samples were packaged using styrofoam boxes for analysis at the Soil Laboratory, IPB University.

\section{$\mathrm{N}_{2} \mathrm{O}$ Gas Emission Analysis and Calculation}

Gas samples were analyzed using Gas Chromatography (GC) (SRI-8610C) following the procedure of Chen et al. (2010). The gas sample is inserted into the GC using a $3 \mathrm{ml}$ syringe; then, the GC will read the peak gas $\mathrm{N}_{2} \mathrm{O}$ on a simple peak application. The simple peak application will read the area from the peak of the $\mathrm{GC}$ reading graph, the site is recorded and tabulated for later use in calculating emissions. The $\mathrm{N}_{2} \mathrm{O}$ gas in the GC is read with an Electron Capture Detector (ECD) for a maximum of 6 minutes. Two injections were performed as replicates for each sample, and calibration was performed every 20 sample injections (10 samples). The standard gas calibration uses pure N2 gas with a concentration of $330 \pm 10 \mathrm{ppb}$. This calibration aims to neutralize the column detector in the $\mathrm{GC}$ after sample injection. Calculation of $\mathrm{N}_{2} \mathrm{O}$ gas emissions using the equation according to the IAEA (1992).

$$
\mathrm{F}=\frac{d c}{d t} x \frac{V c h}{A c h} x \frac{m W}{m V} x \frac{273.2}{273.2+T}
$$

The Data from the analysis of emission calculations were used in regression analysis, statistical and descriptive analysis. Multi-variable linear regression analysis was employed to understand the relationship of $\mathrm{N}_{2} \mathrm{O}$ gas emissions to the environmental parameters. The Wilcoxon test was used to understand the spatial variation of $\mathrm{N}_{2} \mathrm{O}$ gas emissions. All statistical tests in this study used a confidence interval of $p<0.05$.

\section{RESULT AND DISCUSSION}

\section{Characteristics of Study Location}

Kampar Peninsula is a tropical peat forest area which has an area of about 722.929 ha. This ombrotrophic peat area, which is characterized by high acidity and nutrient-poor, was formed about 8000 years ago (Deshmukh et al., 2020). Kampar Peninsula is the largest peat hydrological unit (KHG) in Riau Province which is located between two main rivers, the Siak River and the Kampar River. Kampar Peninsula has a tropical climate, and based on data from the Meteorology, Climatology and Geophysics Agency from 1997 to 2017, 
the average monthly air temperature ranges from 29 to $30{ }^{\circ} \mathrm{C}$, with average annual rainfall over the last five years (from 2014 to 2018) is $1800 \mathrm{~mm}$ (Deshmukh et al., 2020).

According to Miettinen et al. (2016) Kampar Peninsula peat forest has land cover characteristics that are dominated by natural forest, industrial plantation forest, and community agricultural areas. Natural forest and acacia plantation forest dominate the land cover in this area up to $80 \%$. Natural forest is also referred to as natural peat swamp forest (Miettinen et al., 2016). The range of tree height in this research location is between 28-35 m, tree density at DBH $>5 \mathrm{~cm}$ reaches 1300 trees per hectare (Deshmukh et al., 2020). The average peat thickness in the conservation forest area was $9 \pm 1 \mathrm{~m}$, the degree of acidity $(\mathrm{pH})$ of the peat surface was around $3.6 \pm 0.1$, and the groundwater level during the study period in the conservation forest fluctuated seasonally depending on rainfall (Figure 3). Rainfall in 2020 at the study site was $1923 \mathrm{~mm}$ with an average ground water level of $-0.32 \pm 0.18 \mathrm{~m}$ (Figure 3).

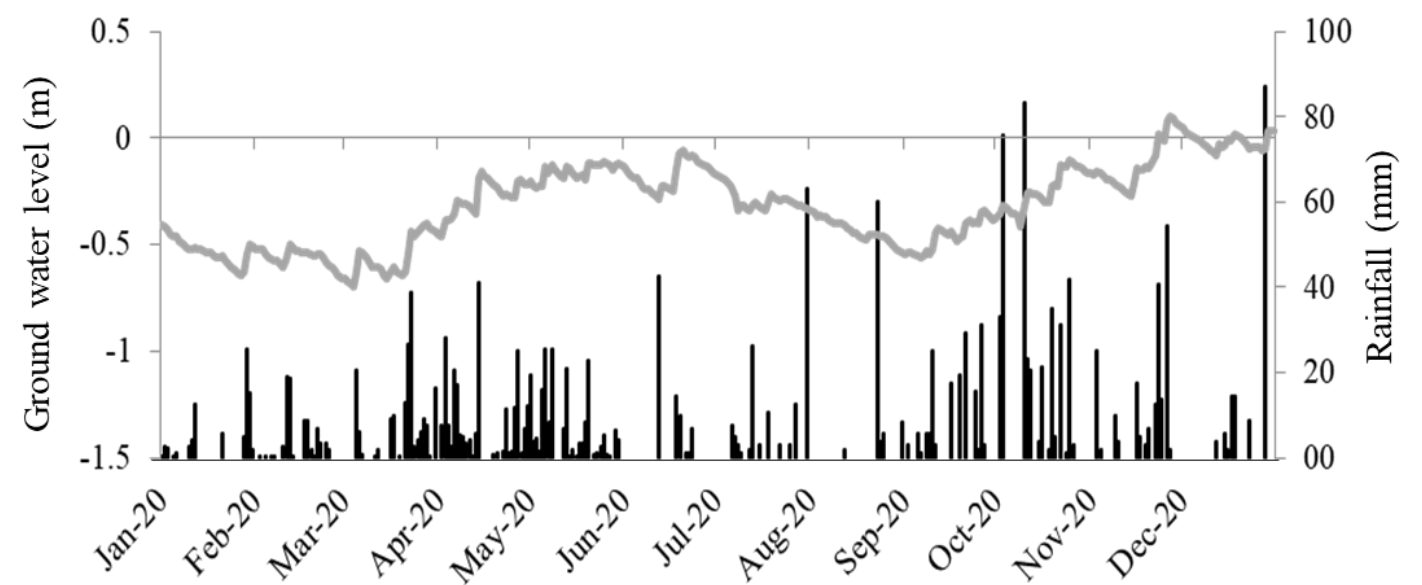

Figure 3 Daily rainfall and ground water level for January-December 2020 at the study site, Kampar Peninsula

The standard deviation of each conservation forest in the $\mathrm{N}_{2} \mathrm{O}$ emissions, soil temperature, and soil moisture parameters represents temporal variation, while the other parameters represent variations in depth (Table 1). Between conservation forest locations (CF1, CF2 and CF3) illustrates the spatial variation. The ground water level (GWL) measured manually during gas sampling did not differ between conservation forest locations, with an average value ranging from -0.44 to $-0.48 \mathrm{~m}$. Soil temperature in CF1 was significantly higher than in CF2 and CF3. Meanwhile, soil moisture in CF1 and CF2 was considerably higher than in CF3. There are significant differences in fiber volume between conservation forest sites, but the average values ranging from 40 to $60 \%$ indicate that the peat maturity level is generally hemic. There was no significant difference in the density value of each peat sampling location with a value of $0.09 \mathrm{~g} / \mathrm{cm}^{-3}$. Porosity also does not show a substantial difference between conservation forest locations with a value close to $94 \%$. Meanwhile, the water-filled pore space showed a significant difference in $\mathrm{CF} 3$ to $\mathrm{CF} 1$ and $\mathrm{CF} 2$, with values ranging from 35 to $46 \%$.

The reaction $(\mathrm{pH})$ of peat soil in each location has an average value of less than 4 , indicating an acidic environmental condition. There is no significant difference in this trait between conservation forest locations. Meanwhile, other soil chemical properties showed significant differences between conservation forest locations, indicating a significant spatial difference in each area. The average C-organic content was in the range of 47.5 to $52.4 \%$ indicating that the peat soil sample was composed of 81.9 to $90.3 \%$ organic matter. Conservation forest ecosystems have an average total $\mathrm{N}$ content in the range of 1.21 to $1.89 \%$, which indicates very high nitrogen stores by weight. However, the average $\mathrm{C} / \mathrm{N}$ ratio ranges from 27.7 to 39.2 , which is very high, meaning that peat material will still decompose if environmental conditions allow. While decomposition of peat material accompanied by the process of $\mathrm{N}$ nutrient immobilization is more dominant than the 446 
mineralization process. There is a very significant spatial difference in the concentration of $\mathrm{NO}_{3} \mathrm{~N}^{-}$at each location, with a value between 0.13 to $0.24 \%$. The concentration of $\mathrm{NH}_{4}-\mathrm{N}$ also had a significantly different value at each location, with values ranging from 668 to $971 \mathrm{ppm}$. Significant spatial differences were also found in the $\mathrm{P}$-available and $\mathrm{K}$-available parameters.

Table $1 \mathrm{~N}_{2} \mathrm{O}$ emissions, environmental parameters, parameters of soil physical and chemical properties of peat in the conservation forest of the Kampar Peninsula

\begin{tabular}{lcccc}
\hline \multicolumn{1}{c}{ Parameter } & Unit & $\mathrm{CF} 1$ & $\mathrm{CF} 2$ & $\mathrm{CF} 3$ \\
\hline $\mathrm{N}_{2} \mathrm{O}$ emissions & $\mathrm{mg} / \mathrm{m}^{2} / \mathrm{day}$ & $0.29 \pm 0.21^{\mathrm{c}}$ & $-0.03 \pm 0.13^{\mathrm{a}}$ & $0.04 \pm 0.66^{\mathrm{b}}$ \\
$\mathrm{GWL}$ & $\mathrm{M}$ & $-0.45 \pm 0.18^{\mathrm{a}}$ & $-0.44 \pm 0.24^{\mathrm{a}}$ & $-0.48 \pm 0.22^{\mathrm{a}}$ \\
Soil temperature & ${ }^{\mathrm{o}}$ & $28.32 \pm 0.92^{\mathrm{b}}$ & $27.87 \pm 1.02^{\mathrm{a}}$ & $27.6 \pm 1.12^{\mathrm{a}}$ \\
Soil moisture & $\%(\mathrm{v} / \mathrm{v})$ & $43 \pm 25^{\mathrm{b}}$ & $40 \pm 2^{\mathrm{b}}$ & $33 \pm 2^{\mathrm{a}}$ \\
Soil physical properties: & & & & \\
$\quad$ Fiber volume & $\%(\mathrm{v} / \mathrm{v})$ & $60.00^{\mathrm{c}}$ & $40.00^{\mathrm{a}}$ & $50.00^{\mathrm{b}}$ \\
Bulk density & $\mathrm{g} / \mathrm{cm}^{3}$ & $0.09^{\mathrm{a}}$ & $0.09^{\mathrm{a}}$ & $0.09^{\mathrm{a}}$ \\
Porosity & $\%(\mathrm{v} / \mathrm{v})$ & $93.83^{\mathrm{a}}$ & $93.51^{\mathrm{a}}$ & $93.81^{\mathrm{a}}$ \\
WFPS & $\%(\mathrm{v} / \mathrm{v})$ & $46^{\mathrm{b}}$ & $43^{\mathrm{b}}$ & $35^{\mathrm{a}}$ \\
Soil chemical properties: & & & & \\
pH & - & $3.24 \pm 0.04^{\mathrm{a}}$ & $3.26 \pm 0.1^{\mathrm{a}}$ & $3.12 \pm 0.12^{\mathrm{a}}$ \\
$\mathrm{C}-$-organic & $\%(\mathrm{w} / \mathrm{w})$ & $52.36 \pm 2.7^{\mathrm{c}}$ & $50.61 \pm 2.04^{\mathrm{b}}$ & $47.48 \pm 2.37^{\mathrm{a}}$ \\
$\mathrm{N}-$ total & $\%(\mathrm{w} / \mathrm{w})$ & $1.89 \pm 0.05^{\mathrm{c}}$ & $1.75 \pm 0.47^{\mathrm{b}}$ & $1.21 \pm 0.31^{\mathrm{a}}$ \\
$\mathrm{C} / \mathrm{N}$ Ratio & - & $27.70^{\mathrm{a}}$ & $28.87^{\mathrm{a}}$ & $39.24^{\mathrm{b}}$ \\
$\mathrm{NO}{ }_{3}-\mathrm{N}$ & $\%(\mathrm{w} / \mathrm{w})$ & $0.24 \pm 0.11^{\mathrm{c}}$ & $0.18 \pm 0.12^{\mathrm{b}}$ & $0.13 \pm 0.06^{\mathrm{a}}$ \\
$\mathrm{NH}_{4}-\mathrm{N}$ & $\mathrm{ppm}$ & $971.47 \pm 802.12^{\mathrm{c}}$ & $667.87 \pm 280.9^{\mathrm{a}}$ & $738.20 \pm 157.14^{\mathrm{b}}$ \\
$\mathrm{P}$ available & $\mathrm{ppm}$ & $49.17 \pm 35.96^{\mathrm{c}}$ & $45.73 \pm 13.13^{\mathrm{b}}$ & $36.50 \pm 40.1^{\mathrm{a}}$ \\
$\mathrm{K}$ available & $\mathrm{ppm}$ & $275.97 \pm 82.44^{\mathrm{c}}$ & $182 \pm 44.3^{\mathrm{b}}$ & $128.37 \pm 117.43^{\mathrm{a}}$ \\
\hline
\end{tabular}

Notes: Different letters following the numbers in the same row indicate significant differences between locations $(\mathrm{p}<0.05) . \mathrm{GWL}=$ ground water level; WFPS $=$ water-filled pore space; $\mathrm{CF} 1=$ conservation forest 1 ; $\mathrm{CF} 2=$ conservation forest $2 ; \mathrm{CF} 3=$ conservation forest 3

\section{$\mathbf{N}_{2} \mathrm{O}$ Gas Emissions}

Spatially, $\mathrm{N}_{2} \mathrm{O}$ gas emissions were significantly different between $\mathrm{CF} 1, \mathrm{CF} 2$, and $\mathrm{CF} 3$, with values of $0.29 \pm 0.21,-0.03 \pm 0.13$, and $0.04 \pm 0.66 \mathrm{mg} / \mathrm{m}^{2} /$ day, respectively (Table 1). The average value of $\mathrm{N}_{2} \mathrm{O}$ gas emissions in conservation forests is $0.10 \pm 0.08 \mathrm{mg} / \mathrm{m}^{2} / \mathrm{day}$ or equivalent to $0.23 \pm 0.19 \mathrm{~kg}-\mathrm{N} / \mathrm{ha} /$ year. From the measurement results (Figure 4), temporally, about $90 \%$ of $\mathrm{N}_{2} \mathrm{O}$ emissions in conservation forests are positive (source), while the rest are negative (sink). Negative $\mathrm{N}_{2} \mathrm{O}$ values were observed in April 2020, which is a wet month condition when sampling $\mathrm{N}_{2} \mathrm{O}$ gas. Monthly $\mathrm{N}_{2} \mathrm{O}$ gas emission in conservation forests ranges from 0.03 to $0.21 \mathrm{mg} / \mathrm{m} 2 /$ day. The highest variability of $\mathrm{N}_{2} \mathrm{O}$ emissions in conservation forests occurred in November 2020, which was the wet month at sampling. There is a significant seasonal pattern as well as high deviation variations throughout the study period. The high variation in deviation is caused by the large spatial variation of emissions at $\mathrm{CF} 1, \mathrm{CF} 2, \mathrm{CF} 3$ locations and the combination of environmental and soil factors. The microtopographic condition of the hood placement is thought to have contributed to the high variability, although it was not part of this study.

The highest monthly $\mathrm{N}_{2} \mathrm{O}$ emissions occurred in November, while the lowest occurred in April 2020 and the highest monthly rainfall occurred in October, and the lowest occurred in June. A significant difference $(\mathrm{p}<0.05)$ was found in the monthly seasonal variation of $\mathrm{N}_{2} \mathrm{O}$ emissions in conservation forests. In the driest month (August) conservation forests contributed $\mathrm{N}_{2} \mathrm{O}$ emissions of $0.08 \mathrm{mg} / \mathrm{m}^{2} /$ day with $36 \mathrm{~mm}$ of rainfall. 
The wettest month (October) $\mathrm{N}_{2} \mathrm{O}$ emission is $0.07 \mathrm{mg} / \mathrm{m}^{2} /$ day with $337 \mathrm{~mm}$ of rainfall. Furthermore, during the wet month period (January, March to June, September to December), $\mathrm{N}_{2} \mathrm{O}$ emissions that occur range from -0.03 to $0.22 \mathrm{mg} / \mathrm{m}^{2} /$ day or an average of $0.10 \mathrm{mg} / \mathrm{m} 2 /$ day with an average rainfall monthly reach $220 \mathrm{~mm}$. The humid season in this study occurred in February and July. In July, the emission of $\mathrm{N}_{2} \mathrm{O}$ was 0.14 $\mathrm{mg} / \mathrm{m} 2 /$ day with an average rainfall of $83 \mathrm{~mm}$. Based on data on $\mathrm{N}_{2} \mathrm{O}$ emissions and monthly rainfall, it can be seen that there is no fixed pattern of relationship between the two. This is because the $\mathrm{N}_{2} \mathrm{O}$ emission process combines the nitrification process of $\mathrm{NH}_{4}{ }^{+}$to $\mathrm{NO}_{3}{ }^{-}$which requires aerobic or drier conditions, and the denitrification process of $\mathrm{NO}_{3}{ }^{-}$to $\mathrm{N}_{2} \mathrm{O}$ which requires anaerobic or wetter conditions.

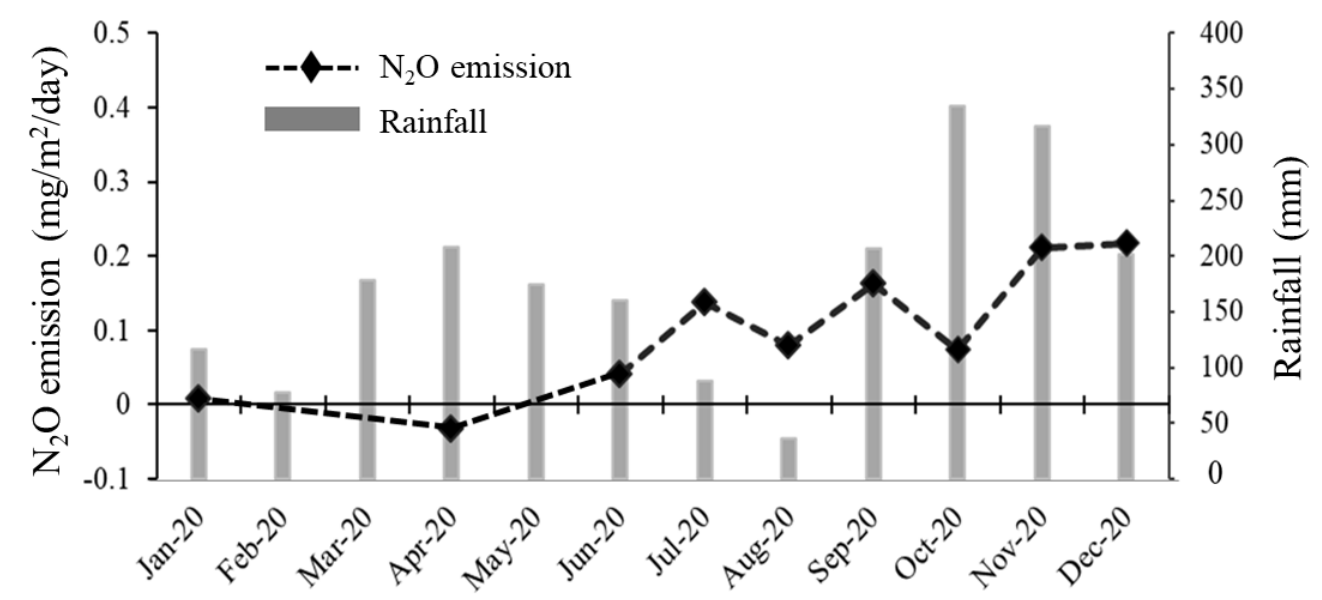

Figure 4 Temporal variation of $\mathrm{N}_{2} \mathrm{O}$ gas emission and monthly rainfall in January-December 2020 in conservation forest, Kampar Peninsula

Conservation forests' annual $\mathrm{N}_{2} \mathrm{O}$ gas emission value is $0.10 \mathrm{mg} / \mathrm{m}^{2} /$ day or equivalent to $0.23 \mathrm{~kg}$ $\mathrm{N} / \mathrm{ha} /$ year. This emission value is still smaller than the results of studies in conservation forests or natural forests conducted by Melling et al. (2007), where $\mathrm{N}_{2} \mathrm{O}$ emissions in natural forests reached $0.70 \mathrm{~kg}-\mathrm{N} / \mathrm{ha} / \mathrm{year}$, Hassler et al. (2017) with an $\mathrm{N}_{2} \mathrm{O}$ emission value of $6.2 \mathrm{~kg}-\mathrm{N} / \mathrm{ha} / \mathrm{year}$, and Hergoualc'h and Verchout, (2020) with an emission value of $1.72 \mathrm{~kg}-\mathrm{N} / \mathrm{ha} /$ year. The value of $\mathrm{N}_{2} \mathrm{O}$ emissions in this study is also still within the emission range from tropical secondary forests, as stated by Erickson et al. (2001) and Davidson et al. (2001), whose values were 0.09 and $9.0 \mathrm{~kg}-\mathrm{N} / \mathrm{ha} / \mathrm{year}$, respectively. Many researchers found that $\mathrm{N}_{2} \mathrm{O}$ emissions from peat swamp forests have a greater value than from mineral soils. This is directly because the peat swamp forest material is organic or has high levels of $\mathrm{C}$-organic and $\mathrm{N}$-total. In addition, peat swamp forests contain high dissolved organic compounds that play an important role in the nitrification and denitrification processes (Erickson et al., 2001; Davidson et al., 2001).

Although there is no fixed relationship pattern between $\mathrm{N}_{2} \mathrm{O}$ emissions and monthly rainfall, there is a significant seasonal variation in $\mathrm{N}_{2} \mathrm{O}$ gas emissions in conservation forests, where $\mathrm{N}_{2} \mathrm{O}$ gas emissions increase in the wet season compared to the dry season. The results of this study are generally consistent with previous studies regarding increased $\mathrm{N}_{2} \mathrm{O}$ gas emissions in tropical rain forests and agricultural sites during periods of high rainfall (Breuer et al., 2000; Melillo et al., 2001; Garcia-Montiel et al., 2003; Kusa et al., 2006). Seasonal variations in $\mathrm{N}_{2} \mathrm{O}$ gas emissions are also associated with seasonal changes in groundwater tables caused by changes in rainfall and soil mineral $\mathrm{N}$ content (Melling et al., 2007). Inorganic nitrogen (mainly $\mathrm{NH}_{4+}$ and $\mathrm{NO}_{3}{ }^{-}$) can occur in the thin water film of soil microsites near oxidative sites. During the rainy season and when the soil layer has the right conditions, soil microbes can efficiently utilize this inorganic $\mathrm{N}$ and produce $\mathrm{N}_{2} \mathrm{O}$ gas (Garcia-Montiel et al., 2003; Davidson et al., 2016). All the results of these studies confirm the importance of measuring $\mathrm{N}_{2} \mathrm{O}$ gas emissions during the rainy season, especially in ecosystems dominated by aerobic conditions, to improve the results of studies on the production of total $\mathrm{N}_{2} \mathrm{O}$ emissions from peat swamp ecosystems. 


\section{Relationship of Environmental Parameters to $\mathrm{N}_{2} \mathrm{O}$ Emissions}

$\mathrm{N}_{2} \mathrm{O}$ gas emissions cannot be separated from the influence of soil parameters, environment, and land changes that have been widely studied (Takakai et al., 2006; Melling et al., 2007; Hadi et al., 2010; Melling et al., 2010; Hatano et al., 2016; Oktarita et al., 2017; Hergoualc'h and Verchout, 2020). Inubushi et al. (2003) revealed that rainfall significantly affects $\mathrm{N} 2 \mathrm{O}$ gas emissions. However, land change is the main factor that causes changes in $\mathrm{N}_{2} \mathrm{O}$ gas emission behavior both temporally and spatially. Keeping natural peatland forests by maintaining biodiversity and keeping them wet can help reduce $\mathrm{N}_{2} \mathrm{O}$ gas emissions from their natural ecosystems. Takakai et al. (2006) expressed different things, which states that changes in soil moisture are very important parameters controlling seasonal changes in $\mathrm{N}_{2} \mathrm{O}$ gas emissions. $\mathrm{N}_{2} \mathrm{O}$ emissions are also strongly influenced by water-filled pore space (WFPS) by 60 to $70 \%$ and an increase in soil $\mathrm{NO}_{3}{ }^{-} \mathrm{N}$ concentrations (Takakai et al., 2006). This is consistent with the results of this study, where the analysis of a single variable on WFPS and $\mathrm{NO}_{3}{ }^{-} \mathrm{N}$ concentrations can explain the variability of $\mathrm{N}_{2} \mathrm{O}$ emissions, respectively, of $53 \%$ and $82 \%$ (Table 2).

Table 2 Equation model of $\mathrm{N}_{2} \mathrm{O}$ emissions on environmental parameters

\begin{tabular}{cccccc}
\hline Data & Model + Variable & $r^{2}$ & p-value & AIC & $N$ \\
\hline $\begin{array}{c}\text { Monthly average } \\
\text { per location }\end{array}$ & $\mathrm{N}_{2} \mathrm{O}=0.152573+\mathrm{GWL}^{*}(-0.4569)+\mathrm{ST}^{*}(0$. & 0.52 & 0.103 & -17.505 & 12 \\
\hline
\end{tabular}

Notes: The environmental, physical, and chemical parameters of the soil used in the model are determined based on the performance of the individual parameter models with indicators of $r 2$ value, $p$-value and AIC (Akaike Information Criterion); *= significant at $\mathrm{p}<0.05 ; \mathrm{GWL}=$ ground water level; $\mathrm{ST}=$ soil temperature; $\mathrm{SM}=$ soil moisture; WFPS= water-filled pore space

Furthermore, Melling et al. (2007) explained related factors controlling $\mathrm{N}_{2} \mathrm{O}$ gas emissions in peat ecosystems, especially natural forests, namely groundwater level, $\mathrm{NH}_{4}-\mathrm{N}$ concentration at $25-50 \mathrm{~cm}$, and soil surface temperature. Melling et al. (2007) explained that peat surface temperature, groundwater level, and C/N ratio significantly affect $\mathrm{N}_{2} \mathrm{O}$ gas emissions. This study is consistent with these results, where the groundwater level, soil surface temperature, and soil moisture explain $52 \%$ of $\mathrm{N}_{2} \mathrm{O}$ emissions. Generally, several experiments conducted by Hadi et al. (2010) and Oktarita et al. (2017) explained that $\mathrm{N}_{2} \mathrm{O}$ gas emissions increased with $\mathrm{N}$ fertilizer. In this study, the concentrations of $\mathrm{NH}_{4}-\mathrm{N}$ and $\mathrm{NO}_{3}-\mathrm{N}$ became the parameters with the highest $\mathrm{R}^{2}$ values, namely $95 \%$ and $82 \%$, which were in line with the results of the study (Wu and $\mathrm{Mu}$, 2019), which stated that the $\mathrm{pH}$ along with nitrate $\left(\mathrm{NO}_{3}{ }^{-}\right)$and ammonium $\left(\mathrm{NH}_{4}{ }^{+}\right)$in the soil was the most dominant factor controlling $\mathrm{N}_{2} \mathrm{O}$ gas emissions.

In general, the groundwater level is one of the factors most often expressed as controlling $\mathrm{N}_{2} \mathrm{O}$ gas emissions in peat ecosystems. This is because the high-water table can cause anaerobic conditions in peat soil which are important for the denitrification process and the thickness of the aerobic layer that determines the volume of soil for the nitrification process (Melling et al., 2007). Both processes must coincide to produce $\mathrm{N}_{2} \mathrm{O}$ gas emissions. A pH value below 4 indicates an ecosystem in acidic conditions or low base saturation, reducing nitrification activity (Šimek and Cooper, 2002; Strauss et al., 2002). The inhibition of the nitrification process causes the accumulation of $\mathrm{NH}_{4}-\mathrm{N}$ in the soil which also causes a decrease in $\mathrm{N}_{2} \mathrm{O}$ production. The high concentration of $\mathrm{NH}_{4}{ }^{-} \mathrm{N}$ is also possible as a result of the low population and nitrifier activity. But on the other hand, the accumulation of $\mathrm{NH}_{4}-\mathrm{N}$ can increase the efficiency of nitrogen utilization in an ecosystem, both absorbed by plants and utilized by bacteria. It explained how the concentration of $\mathrm{NH}_{4}{ }^{-} \mathrm{N}$ significantly affects $\mathrm{N}_{2} \mathrm{O}$ emissions in this study (Hadi et al., 2010; Oktarita et al., 2017; Wu and $\mathrm{Mu}, 2019$ ). 


\section{CONCLUSION}

Annual $\mathrm{N}_{2} \mathrm{O}$ gas emission in conservation forest is $0.23 \pm 0.19 \mathrm{~kg}-\mathrm{N} / \mathrm{ha} / \mathrm{year}$. The high spatial-temporal variation causes a high value of uncertainty in the calculation of annual emissions. Improving sampling frequency through spatial and temporal can help to overcome the uncertainty of $\mathrm{N}_{2} \mathrm{O}$ emission quantification in the future. $\mathrm{N}_{2} \mathrm{O}$ gas emissions vary seasonally, where $\mathrm{N}_{2} \mathrm{O}$ emissions are lower in the dry season and increase in the wet season period. The regression test results on $\mathrm{N}_{2} \mathrm{O}$ gas emissions and environmental parameters explain that $\mathrm{N}_{2} \mathrm{O}$ emissions are dominantly controlled by groundwater level, soil surface temperature, and soil moisture. Keeping peat forests in their natural state can help reduce $\mathrm{N}_{2} \mathrm{O}$ emissions in their natural state, along with the fact that conversion of peatlands leads to increased $\mathrm{N}_{2} \mathrm{O}$ gas emissions in peat ecosystems.

\section{ACKNOWLEDGMENT}

We would like to thank our colleagues at Asia Pacific Resources International Limited (APRIL) for their technical and theoretical assistance in carrying out this research. The author would say the gratitude to the supervisors that had been provide analytical guidance for the research. This research was fully funded by APRIL through peatland science department and greenhouse gas monitoring division.

\section{REFERENCES}

[IAEA] International Atomic Energy Agency. 1992. Manual on Measurement of Methane and Nitrous Oxide Emission from Agricultural. Austria (AT): FAO.

[IPCC] Intergovernmental Panel on Climate Change. 2014. 2013 Supplement to the 2006 IPCC Guidelines for National Greenhouse Gas Inventories: Wetlands. Switzerland (CH): IPCC.

Arvelyna Y, Prayoto, Maryani R, Sato T. 2019. Observation of peat dome and peatland subsidence using DInSAR analysis on PALSAR-2 data (study case : Kampar Peninsula, Central Sumatra) (EO RA1). ReseachGate. doi: 10.13140/RG.2.2.22100.65929.

Breuer L, Papen H, Butterbach-Bahl K. 2000. $\mathrm{N}_{2} \mathrm{O}$ emission from tropical forest soils of Australia. J Geophys Res Atmos. 105(D21): 26353-26367.

Chen GC, Tam NFY, Ye Y. 2010. Summer fluxes of atmospheric greenhouse gases $\mathrm{N}_{2} \mathrm{O}, \mathrm{CH}_{4}$ and $\mathrm{CO}_{2}$ from mangrove soil in South China. Sci Total Environ. 408(13): 2761-2767. doi: 10.1016/j.scitotenv. 2010.03.007.

Davidson EA, Bustamante MM, de Siqueira Pinto A. 2001. Emissions of nitrous oxide and nitric oxide from soils of native and exotic ecosystems of the Amazon and Cerrado regions of Brazil. ScientificWorldJournal. 1(S2): 312-319.

Davidson EA, Kanter D, Reis S, Bekunda M, Clare M, Kanter DR, Zhang X, Mauzerall DL, Malyshev S, Shevliakova E. 2016. The importance of climate change and nitrogen use efficiency for future nitrous oxide emissions from agriculture. Environ Res Lett. 11(9): 1-9. doi: http://dx.doi.org/10.1088/17489326/11/9/094003.

Deshmukh CS, Julius D, Evans CD, Nardi, Susanto AP, Page SE, Gauci V, Laurén A, Sabiham S, Agus F, et al. 2020. Impact of forest plantation on methane emissions from tropical peatland. Glob Chang Biol. 26(4): 2477-2495. doi: 10.1111/gcb.15019.

Erickson H, Keller M, Davidson EA. 2001. Nitrogen oxide fluxes and nitrogen cycling during postagricultural succession and forest fertilization in the humid tropics. Ecosystems. 4(1): 67-84. doi: $10.1007 / \mathrm{s} 100210000060$.

Fowler D, Pyle JA, Raven JA, Sutton MA. 2013. The global nitrogen cycle in the twenty-first century: introduction. Philos Trans R Soc B Biol Sci. 368(1621): 3-4. doi: 10.1098/rstb.2013.0120.

Garcia-Montiel DC, Steudler PA, Piccolo M, Neill C, Melillo J, Cerri CC. 2003. Nitrogen oxide emissions following wetting of dry soils in forest and pastures in Rondônia, Brazil. Biogeochemistry. 64(3): 319- 
336. doi: https://doi.org/10.1023/A:1024968802018.

Hadi A, Jumadi O, Inubushi K, Yagi K. 2010. Mitigation options for $\mathrm{N}_{2} \mathrm{O}$ emission from a corn field in Kalimantan, Indonesia. Soil Science and Plant Nutrition. 54(4): 644-649. doi: 10.1111/j.17470765.2008.00280.x.

Hassler E, Corre MD, Kurniawan S, Veldkamp E. 2017. Soil nitrogen oxide fluxes from lowland forests converted to smallholder rubber and oil palm plantations in Sumatra Indonesia. Biogeosciences. 14: 2781-2798. doi: https://doi.org/10.5194/bg-14-2781-2017.

Hatano R, Toma Y, Hamada Y, Arai H, Susilawati HL, Inubushi K. 2016. Methane and nitrous oxide emissions from tropical peat soil methane and nitrous oxide emissions. Springer link. doi: 10.1007/978-4-43155681-7.

Hergoualc'h K, Verchot L. 2011. Stocks and fluxes of carbon associated with land use change in Southeast Asian tropical peatlands: A review. Global Biogeochem Cycles. 25(GB2001): 1-13. doi: 10.1029/2009GB003718.

Inubushi K, Furukawa Y, Hadi A, Purnomo E, Tsuruta H. 2003. Seasonal changes of Co2, CH4 and N2O fluxes in relation to land-use change in tropical peatlands located in coastal area of South Kalimantan. Chemosphere. 52(3):603-608.doi:10.1016/S0045-6535(03)00242-X.

Karyanto O, Susanti A, Qomar N, Wardhana W. 2015. Developing Carbon-Incentive Mechanisms for Forest Resource Management toward the Emission Reduction in Kampar Peninsular peatlands: Establishing Baseline Activities. Yogyakarta (ID): Gadjah Mada University. doi: 10.13140/RG.2.1.3108.9763.

Khare N, Singh D, Kant R, Khare P. 2020. Global Warming and Biodiversity. In: Rathoure AK, Chauhan PB, editors. Current State and Future Impacts of Climate Change on Biodiversity. Delhi (IN): IGI Global. p 1-10. doi: 10.4018/978-1-7998-1226-5.ch001

Kusa K, Hu R, Sawamoto T, Hatano R. 2006. Three years of nitrous oxide and nitric oxide emissions from silandic andosols cultivated with maize in Hokkaido, Japan. Soil Sci Plant Nutr. 52(1): 103-113. doi: doi.org/10.1111/j.1747-0765.2006.00009.x.

Masganti. 2013. Teknologi Inovatif Pengelolaan Lahan Suboptimal Gambut dan Sulfat Masam Untuk Peningkatan Produksi Tanaman Pangan. Jurnal Pengembangan Inovasi Pertanian. 6(4): 187-197. doi: 10.21082/pip.v6n4.2013.187-197.

Melillo JM, Steudler PA, Feigl BJ, Neill C, Garcia D, Piccolo MC, Cerri CC, Tian H. 2001. Nitrous oxide emissions from forests and pastures of various ages in the Brazilian Amazon. J Geophys Res Atmos. 106(D24): 34179-34188.

Melling L, Hatano R, Goh KJ. 2007. Nitrous oxide emissions from three ecosystems in tropical peatland of Sarawak, Malaysia. Soil Sci Plant Nutr. 53(6): 792-805. doi: 10.1111/j.1747-0765.2007.00196.x.

Melling L, Hatano R, Goh KJ, Melling L, Hatano R, Goh KJ. 2010. Soil science and plant nutrition nitrous oxide emissions from three ecosystems in tropical peatland of Sarawak, Malaysia nitrous oxide emissions from three ecosystems in tropical peatland of Sarawak, Malaysia. Soil Science Plant Nutrition. 53(6): 792-805. doi: 10.1111/j.1747-0765.2007.00196.x.

Miettinen J, Shi C, Liew SC. 2016. Land cover distribution in the peatlands of Peninsular Malaysia, Sumatera and Borneo in 2015 with changes since 1990. Glob Ecol Conserv. 6: 67-78. doi: http://dx.doi.org/10.1016/j.gecco.2016.02.004.

Nunes LJ, Meireles CI, Gomes CJP, Ribeiro NMA. 2020. Forest contribution to climate change mitigation: Management oriented to carbon capture and storage. Climate. 8(2): 1-21. doi: 10.3390/cli8020021.

Oktarita S, Hergoualc'H K, Anwar S, Verchot L V. 2017. Substantial $\mathrm{N}_{2} \mathrm{O}$ emissions from peat decomposition and $\mathrm{N}$ fertilization in an oil palm plantation exacerbated by hotspots. Environ Res Lett. 12(10): 1-13. doi: 10.1088/1748-9326/aa80f1.

Sakabe A, Itoh M, Hirano T, Kusin K. 2018. Ecosystem-scale methane flux in tropical peat swamp forest in Indonesia. Glob Chang Biol. 24(11): 5123-5136. doi: 10.1111/gcb.14410.

Šimek M, Cooper JE. 2002. The influence of soil pH on denitrification: Progress towards the understanding of 
this interaction over the last 50 years. Eur J Soil Sci. 53(3):345-354. doi: https://doi.org/10.1046/j.13652389.2002.00461.x.

Strauss EA, Mitchell NL, Lamberti GA. 2002. Factors regulating nitrification in aquatic sediments: Effects of organic carbon, nitrogen availability, and pH. Can J Fish Aquat Sci. 59(3): 554-563. doi: 10.1139/F02032.

Takakai F, Morishita T, Hashidoko Y, Darung U, Kuramochi K, Dohong S, Limin SH, Hatano R. 2006. Effects of agricultural land-use change and forest fire on $\mathrm{N}_{2} \mathrm{O}$ emission from tropical peatlands, Central Kalimantan, Indonesia. Soil Sci Plant Nutr. 52(5): 662-674. doi: 10.1111/j.1747-0765.2006.00084.x.

Werner C, Butterbach-Bahl K, Haas E, Hickler T, Kiese R. 2007. A global inventory of $\mathrm{N}_{2} \mathrm{O}$ emissions from tropical rainforest soils using a detailed biogeochemical model. Global Biogeochem Cycles. 21(3): 118. doi: 10.1029/2006GB002909.

Wu B, Mu C. 2019. Effects on greenhouse gas $\left(\mathrm{CH}_{4}, \mathrm{CO}_{2}, \mathrm{~N}_{2} \mathrm{O}\right)$ emissions of conversion from over-mature forest to secondary forest and Korean pine plantation in Northeast China. Forests. 10(9): 1-18. doi: 10.3390/f10090788. 